\title{
Ethnobotanical survey of medicinal plants used to manage High Blood Pressure and Type 2 Diabetes Mellitus in Bitterfontein, Western Cape Province, South Africa
}

\author{
Denver Davids, Diana Gibson and Quinton Johnson
}

\begin{abstract}
Ethnopharmacological relevance: The aim of this study was to identify and document medicinal plants used to manage High Blood Pressure and Type 2 Diabetes Mellitus in Bitterfontein, Western Cape Province, South Africa.

Methods: One hundred and twelve (112) respondents were interviewed between August 2014 and September 2015 through semi-structured surveys to gather data on the percentage of people who had been diagnosed with High Blood Pressure and/or Type 2 Diabetes Mellitus and to determine the frequency of medicinal plant and allopathic medicine use. Twelve (12) key respondents were subsequently selected, using a non-probability snowball sampling method. They were interviewed in-depth concerning their plant practices and assisted with plant collection.

Results: Twenty-four plant (24) species belonging to 15 families were identified for the management of High Blood Pressure and Type 2 Diabetes Mellitus. The most frequently reported families were Asteraceae (20.8\%), Lamiaceae (16.67\%), Crassulaceae (8.33\%) and Aizoaceae (8.33\%). The remaining (45.54\%) were evenly split over eleven families- Fabaceae, Amaryllidaceae, Anacardiaceae, Capparaceae, Geraniaceae, Apiaceae, Convolvulaceae, Apocynaceae, Rutaceae, Asphodelaceae and Thymelaeaceae. The most commonly used plant species overall was Lessertia frutescens (96.55\%). The most frequently used plant parts included leaves (57.63\%) roots/bulbs (15.25\%) and stems (11.86\%), mostly prepared as infusions or decoctions for oral administration.

Conclusions: Medicinal plants are widely used by High Blood Pressure and Type 2 Diabetes Mellitus sufferers. They employ diverse plant species to manage both conditions. In addition, some sufferers often use prescribed allopathic medication, as well as medicinal plants, but at different intervals. Despite high usage the plants identified are not currently threatened (Red Data list status: least concern).
\end{abstract}




\section{Introduction}

High Blood Pressure (HBP) and Type 2 Diabetes Mellitus (T2DM) are growing concerns worldwide. The rate of new cases and number of deaths caused by these two non-communicable diseases are a public health concern: alongside infectious diseases such as human immuno-deficiency virus (HIV) and tuberculosis (TB) (Cheung and Chao, 2012). According to the World health Statistics Report, one in three adults worldwide has HBP and one in ten has T2DM (World Health Organisation $(2003,2012)$ ). There is substantial overlap between the two conditions in aetiology and disease mechanisms. Many of those affected by T2DM also have, or go on to develop, HBP - a condition known as Diabetic Hypertensive (Balogun and Salako, 2011). The latter is a common condition in which the flow of blood through the arteries occurs at pressures higher than normal. In its chronic state it is called Hypertension, i.e. when the blood pressure is higher than 140 over $90 \mathrm{mmHg}$ (Carretero and Oparil, 2000). South Africans over the age of 50 are especially at risk and currently have one of the highest occurrences of HBP in the world (Lloyd-Sherlock et al., 2014a).

T2DM is defined as a random blood glucose level (RGB) above P11.1 mmol/L, or RBG $<11.1 \mathrm{mmol} / \mathrm{L}$ (Bailey et al., 2016). T2DM is a chronic condition that affects the way in which the body metabolizes sugar (glucose). The prevalence of T2DM is escalating worldwide (Kadima and Tumbo, 2013). In South Africa, approximately $6 \%$ of the population suffers from T2DM (Bertram et al., 2014). According to the World Health Organisation's (WHO) (2016), this condition is the fifth leading cause of death in South Africa. In the Western Cape Province, however, little information is available on the occurrence of T2DM. In prevalence surveys conducted in the Province, the statistics of T2DM fluctuates from rural to urban areas and among different population groups (Erasmus et al., 2012; Hughes et al., 2013; Health24, 2014; Bailey et al., 2016). The prevalence of T2DM is thought to be especially high among the coloured ${ }^{1}$ population (Erasmus et al., 2012). This was the case in our study site, Bitterfontein. T2DM is also one of the biggest causes of natural death in the Western Cape (Bothma, 2014). HBP and T2DM are risk factors for an array of associated conditions such as cardiovascular disease, renal, neurovascular and retinal complications ((Balogun and Salako, 2011; Bertram et al., 2014). Given that there is a high correlation between HBP and T2DM, it is important to consider their co-occurrence, since they are pre-eminent in relation to morbidity and mortality.

It is not clear from available literature how HBP and T2DM are managed in semirural areas in the Western Cape where access to health care facilities, diagnosis and treatment may not be optimal (Health24, 2014). Little is known about the use of traditional herbal medicine (THM) to manage the above conditions and ethnobotanical studies do not always compare their findings with scientific studies that investigate the phytochemical effects of THM. The use of THM in combination with allopathic medicine has also not been studied extensively. At the 
same time, there has been increased concern about the cost and availability of pharmaceuticals, especially in rural areas. Prescribed medicines used for HBP and T2DM can produce side effects such as headaches, nausea, vomiting, stomach pain, constipation, diarrhoea, weakness and fatigue. People often turn to THM to combat such symptoms and to manage their health, contributing to a growing tendency to consider THM that is known to promote good health, with minimal side effects. This trend has led academic researchers, as well as the pharmaceutical industry, to consider THM as a potential source of new, safe and affordable alternatives (Day, 1998). THM, on the whole, are also believed to be relatively safe and harmonious with biological systems (Atal, 1983; Erasto, 2003). The practice of using nature as a source of medicine dates back in history and various current medicines were originally derived from plants. As many herbal remedies have not been clinically tested, they are classified as complementary and alternative medicines and are considered to be generally affordable and accessible. In South Africa a big informal market in THM exists (Street and Prinsloo, 2013).

South Africa has a pluralistic health care system (Levine, 2012; Wreford et al., 2006) and the usage of what is referred to as "traditional" medicines is often reported to be as high as $80 \%$, although the frequency of use fluctuates from one province to another and between rural and urban areas (Dold and Cocks, 2002; Nxumalo et al., 2011; Davids et al., 2014; Hughes et al., 2013). In the Western Cape, and especially in the Matzikama district, knowledge and usage of medicinal plants is often associated with the knowledge of elderly people (Davids, 2012), bossiesdokters (bush doctors/herbalists) (Cohen, 2009, 2013) and Rastafari bush doctors (Nortje, 2011; Philander, 2011; Philander et al., 2014) and it is often intermingled with a range of knowledge heritages. The most prevalent in Matzikama is frequently termed Khoisan medicine (Low, 2007) or "Cape herbal medicine" (van wyk, 2008). The latter nomenclature intimates the intermixing of Khoisan ancestral healing knowledge and practices concerning medicinal plants with historical "Cape Dutch" influences in the Western Cape. Locally sourced medicinal plants fall under the rubric of "traditional" medicine in South Africa. Although the reality of pluralistic healing systems is accepted, notions of "traditional" medicine are nonetheless fraught with epistemological dilemmas (Ellen and Harris, 2000; Gibson, 2011). South African discourses on traditional medicine tend to draw on "traditional" knowledge/s in contradistinction to "Western" or "scientific" knowledge. HBP and/or T2DM sufferers, however, are often informed by both in their health care choices. This paper draws on the aforementioned debates to define THM as local knowledge, principally orally transmitted, which is common practice in the everyday life of users. THM knowledge is empirical and its display is somewhat repetitive but it is also transformative, it is produced and reproduced, and can be lost. The knowledge is dispersed, practical, and broadly holistic (Ibid: 5). For the purpose of this study and to avoid confusion, traditional herbal medicine utilised in the Matzikama district will hereafter be referred to as THM. 
In South Africa, recent studies suggest that THM is used to manage the symptoms of HBP. For instance, a study conducted by Hughes et al. (2013) in Langa, Cape Town, found that $51 \%$ of their study sample used THM for HBP. Forty eight percent (48\%) used THM between one and three times a day over extended periods. There is also increased interest in the use of THM for the management of T2DM (Erasto et al., 2005). The aim of this study was to identify and document medicinal plants used to manage HBP and T2DM in Bitterfontein, Matzikama municipal district, Western Cape Province, South Africa. Since much of the research conducted in the Western Cape Province on HBP and T2DM focuses on the Cape Metropole, are older studies and/or are population specific (Levitt et al., 1999; Idemyor, 2010; Erasmus et al., 2012; Bailey et al., 2016), information about the prevalence of both conditions varies. The number of people medically diagnosed with one, or both, of these conditions therefore had to be ascertained and the utilisation of allopathic medicines as well as medicinal plants had to be deduced. The latter was subsequently compared with extant literature to gain insight into related scientific research, as well as to establish the plants' conservation status.

\section{Materials and methods}

2.1 Study design and sample size

A cross sectional descriptive research methodology was used to explore THM use and practices. The study was designed to gather data at three different levels in three progressive phases. First, a semi-structured survey was designed and used to gather data on the number of people previously diagnosed by health care providers with the target conditions, as well as the frequency of THM use over the previous four weeks. A simple random sampling method was used to screen all households and select one hundred and twelve (112) eligible participants. Eligibility criteria included participants who were above eighteen (18) years of age and had previously been medically diagnosed with the target condition(s). ${ }^{2}$ A blood pressure reading higher than 140 over $90 \mathrm{mmHg}$ and a $\mathrm{RBG}<7.8 \mathrm{mmol} / \mathrm{L}$ in participants with previous diagnoses of T2DM were considered acceptable levels for participation. These readings were initially done at the clinic and are then regularly tested by home based care staff. Participants were also questioned about allopathic medicine and THM use. Secondly, in-depth semi-structured interviews were conducted with twelve (12) key participants, selected through a non-probability "snowball" sampling method (Heckathorn, 2011). The municipal councillor for the Bitterfontein ward initially mediated the researchers into the local community, and assisted in identifying key participants who were especially knowledgeable about THM. These participants included community elders, practising bossiesdokters and Rastafari bush doctors. These key participants were also regularly consulted by locals about THM to manage HBP and T2DM. The third and final phase comprised two rounds of plant collection during the spring and summer months of 2014 and 2015. 


\subsection{Study area}

Bitterfontein is a small semi-rural village situated in the Matzikama municipal area. The village is the northernmost settlement on the border of the Western and Northern Cape Provinces and lies three hundred and eighty six (386) kilometres from Cape Town. Bitterfontein is surrounded by different landscapes, from the flowing granite hills of the Knersvlakte to the Hardeveld with its hard, dry soil and scattered bushy quartz fields. According to the 2011 Census, Bitterfontein had a population of $986 \mathrm{in}$ an area of $39.90 \mathrm{~km}^{2}$. There are 231 households. The majority of the population is "coloured" (91.28\%) and most of the inhabitants are Afrikaans speaking (97.34\%). More than half (50.71\%) of the population are female and 49.29\% are male (Statistic South Africa, 2011). Economic activity in the area comprises tourism, agriculture and mining. Poverty and high rates of unemployment (67\%) are often seen as contributing factors in studies of poor health and non-communicable diseases such as HBP and T2DM (Matzikama Municipality, 2013). The village is serviced by a small satellite clinic. (Fig. 1).

\subsection{Data collection}

The first round of data collection began with surveys in August 2014 and ended in September 2014. The surveys were administered by eight trained field workers with background training in medical anthropology and ethnobotany. One local fieldworker acted as a field guide and assistant. Field workers screened all houses in Bitterfontein, asking the screening questions: are you above the age of eighteen years? have you or anyone in the household been medically diagnosed with HBP and or T2DM? If a person answered yes to the above, (s)he was asked whether they had used THM and/or allopathic medicines during the previous four weeks. The aims and objectives of the study were explained, an information leaflet was provided and informed consent recorded if the person was willing to participate in the study. If a participant did not wish to sign a consent form, verbal consent was accepted and audio-recorded. Interviews were conducted in the preferred language of the participant (English or Afrikaans).

In the second round of data collection, selected participants were revisited. This key group included six bossiesdokters, three Rastafari bush doctors and three knowledgeable old people. There was an equal number of male and female participants. Written informed consent was again confirmed by each participant after the aims and objectives of the study were explained in the participants' preferred language (mostly Afrikaans). The interviews were tape recorded and extensive field notes and photographs were taken with the consent of the participants. The topic schedule for the interviews included probing questions to enhance consistency and accuracy in participants' responses and to compare responses. The second round of data collection took place from September 2014 to April 2015. 
The third round of research involved plant collection from November to December 2014 and March 2015. Because the research site was visited during all the seasons, the plants were observed in drought conditions and rainy season. The plant collection was undertaken with the assistance of a botanist and all of the key participants on different occasions. Plants were collected three-fold, numbered and dry-pressed in the field. Together with plant pressings, the collection team noted vernacular plant names, their locality, GPS coordinates, habitat, plant distribution when collected, plant parts used, preparation and administration methods. Each collected specimen included leaves, stems, flowers and fruits where available. For small herbaceous plants, the whole plant was collected. The collected specimens were deposited at the Herbarium of the University of the Western Cape (UWC) together with collection/field notes and a comprehensive reference collection with representative specimens. The plant names were updated using Kew's plant list http://www.theplantlist.org/(accessed and updated: 28.02.2016).

\subsection{Data analyses}

After the surveys were completed, they were checked for quality and completeness. Data was analysed using IBM SPSS V.22.0. Standard descriptive measures were used to describe the study sample and responses to the questionnaire. Chi-square tests were used when making comparisons between two groups. All percentage distributions were calculated based on non-missing values. No amendments were made for missing data or multiple comparisons.

The in-depth, semi-structured interviews were analysed using a thematic content analysis method (Heckathorn, 2011). After the interviews, the derived data underwent numerous stages of analysis, initially transcribing the material and then checking for coherence and saturation. The material from different respondents were compared with each other to identify patterns and themes. Segments of data were then coded. The emerging themes were linked to sections of data with associated codes such as plant practices, method of administration and path of knowledge. When no new information arose from the material and when no new codes or themes emerged, the authors agreed that saturation had been achieved. 


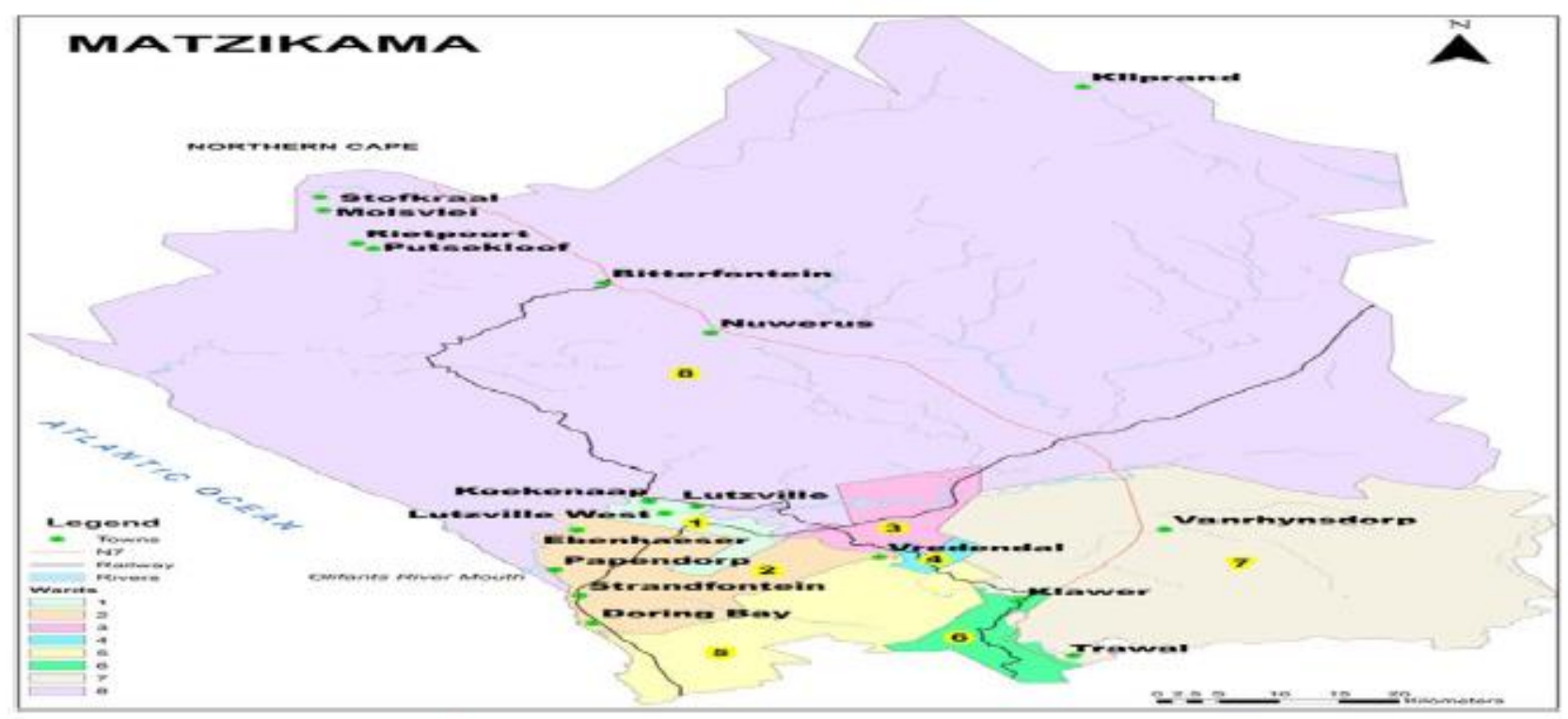

Fig. 1. Bitterfontein. Matzikama Municipality. Western Cape Province. Source: Lionel Phillips.

\subsection{Ethical approval and considerations}

Ethical approval for this study was obtained from the Senate Ethics Committee, University of the Western Cape (Project ethics number: 13/8/3). A plant collection permit was acquired from Cape Nature (Permit number: 0028AAA008-00221). Informed consent was obtained from each participant. Participants were informed of the aims and objectives of this research and interviewed in their preferred language (Afrikaans or English).

Before the research began the local Councillors representing the Bitterfontein constituency, employees of the Matzikama Municipality and the local community participated in a seminar in which a Memorandum of Understanding was agreed on and signed, and the community's participation and benefit sharing discussed. It was made clear that the study was for research purposes only, and not for product development.

\section{Results and discussion}

\subsection{Socio-demographics of participants}

In the study sample, $34.8 \%$ of participants were male and $65.2 \%$ were female. The majority of participants spoke Afrikaans (98.2\%) and most were of the Christian denomination (94.6\%). Participants' ages ranged from 19 to 87 years. Forty per cent (40.2\%) of the participants had primary education, $43.8 \%$ secondary education, $3.6 \%$ tertiary education and $12.5 \%$ had no formal education. More than half of the sample population (50.9\%) relied on state funded grants such as pensions (33.93\%) and disability grants (16.97\%). Only $10.7 \%$ held full-time jobs and a further $34.8 \%$ were unemployed. The remaining cohort were employed parttime $(1.8 \%)$ or self-employed $(1.8 \%)$. The total sample of participants who were 
employed (14.3\%), derived their income from work as farm labourers, keeping and selling livestock, informal trade and providing labour for mines in the region. A large proportion of participants (59.8\%) fell within the RosR1999 per month income category. None of the participants in this study had medical aid insurance. Table 1 specifies the socio-demographic characteristics of participants in Bitterfontein.

\subsection{Medicinal plants used for HBP and T2DM}

Twenty-four (24) plant species belonging to 15 families were documented for the management of HBP and T2DM. The plant species, family, vernacular names (specific to the study area), reported use and part of plant used are presented in Table 2. More than half (52.79\%) of the study sample reported the active use of THM, i.e. they had utilised THM at least once a day for the previous two weeks at the time of interview. Non-active users (21.11\%) utilised THM at least once a week in the four weeks prior to the interviews. Lessertia frutescens was the most commonly reported plant species (96.55\%) among all THM users in this study. The other plant species were not as significantly reported, and were often used in concoctions together with $\mathrm{L}$. frutescens. The most frequently reported families were Asteraceae (20.8\%), Lamiaceae (16.67\%), Crassulaceae (8.33\%) and Aizoaceae (8.33\%). The remaining (45.54\%) were evenly split over eleven families-Fabaceae, Amaryllidaceae, Anacardiaceae, Capparaceae, Geraniaceae, Apiaceae, Convolvulaceae, Apocynaceae, Rutaceae, Asphodelaceae and Thymelaeaceae. Some of these families have been documented and researched for their anti-hypertensive and anti-diabetic potential (Sunmonu and Afolayan, 2010; Hughes et al., 2013; Chethan et al., 2014), suggesting their importance for the management of HBP and T2DM.

\subsection{Inventory of plant species used for HBP and T2DM}

The claimed therapeutic indications of some of the plants reportedly used to manage HBP and T2DM in this study have partially been validated by studies in experimental animals, while others have been documented for their medicinal use in ethnobotanical studies. L. frutescens for example, is the most frequently used plant species in this study, widely utilised in the Western Cape and along the west coast of South Africa for the treatment of T2DM (van wyk and Albrecht, 2008; Rood, 1994; van wyk and Gericke, 2000; van wyk et al., 1997). L. frutescens has been investigated as a possible hypoglycaemic agent for managing T2DM, through stimulating glucose uptake in pre-diabetic rats (Chadwick et al., 2007). Because of its capacity to normalize insulin levels in diabetic patients, L. frutescens is considered to be a promising anti-diabetic agent (Sia, 2004). High levels of pinitol in L. frutescens leaves were proposed by Moshe (1998) as a possible explanation for the anti-diabetic effect of its extract. Tai et al. (2004) found that L. frutescens contained not only pinitol, but also non-protein amino acid L-canavanine, gamma aminobutyric acid (GABA) and asparganine. The presence of pinitol in L. frutescens leaves was shown in studies to be most probably responsible for the antidiabetic effects of plant extracts. It is reportedly efficacious in decreasing blood 
sugar levels and improves the availability of glucose for metabolic reactions to occur (Bates et al., 2000; van wyk and Albrecht, 2008; Van-Wyk et al., 2005; Deutschländer et al., 2009). The Gamma-aminobutyric acid (GABA) in L. frutescens could be of benefit by lowering HBP (Abe et al., 1995; Dalvi, 2003).

There is always concern regarding the safety of THM. Studies on L. frutescens, however, have indicated little to no side effects. 
Table 1

Socio-demographic characteristics of participants $(n=112)$.

\begin{tabular}{|c|c|c|}
\hline Characteristics & Frequency & Percentage (\%) \\
\hline \multicolumn{3}{|l|}{ Age group (Years) } \\
\hline Less than 20 & 3 & $(2.7)$ \\
\hline $21-30$ & 8 & (7.1) \\
\hline $31-40$ & 22 & (19.6) \\
\hline $41-50$ & 22 & (19.6) \\
\hline $51-60$ & 19 & (16.9) \\
\hline $61-70$ & 22 & (19.6) \\
\hline $71-80$ & 13 & (11.6) \\
\hline $81-90$ & 3 & $(2.7)$ \\
\hline \multicolumn{3}{|l|}{ Gender } \\
\hline Male & 39 & $(34.8)$ \\
\hline Female & 73 & (65.2) \\
\hline \multicolumn{3}{|l|}{ Language } \\
\hline English & 2 & (1.8) \\
\hline Afrikaans & 110 & (98.2) \\
\hline \multicolumn{3}{|l|}{ Religion } \\
\hline Christian & 106 & (94.6) \\
\hline Rastafarian & 5 & $(4.5)$ \\
\hline ATB* & 1 & $(0.9)$ \\
\hline \multicolumn{3}{|l|}{ Level of education } \\
\hline Primary & 45 & $(40.2)$ \\
\hline Secondary & 49 & (43.8) \\
\hline Tertiary & 4 & $(3.6)$ \\
\hline No education & 14 & (12.5) \\
\hline \multicolumn{3}{|l|}{ Employment status } \\
\hline Full-time & 12 & (10.7) \\
\hline Part-time & 2 & (1.8) \\
\hline Self-employed & 2 & (1.8) \\
\hline Unemployed & 39 & $(34.8)$ \\
\hline Other (SFG)* & 57 & (50.9) \\
\hline \multicolumn{3}{|c|}{ Monthly household income } \\
\hline $\mathrm{R} 0 \leq \mathrm{R} 1999$ & 67 & $(59.8)$ \\
\hline R2000 $\leq$ R4999 & 12 & (10.7) \\
\hline R5000 $\leq$ R10999 & 1 & $(0.9)$ \\
\hline DND* & 32 & $(28.6)$ \\
\hline Total & 112 & $(100)$ \\
\hline
\end{tabular}

* ATB: African traditional beliefs * SFG: State funded grant * DND: Did not wish to disclose. 
Table 2

Medicinal plants used for the management of HBP and T2DM.

\begin{tabular}{|c|c|c|c|c|c|c|}
\hline Family & Species & $\begin{array}{l}\text { Voucher } \\
\text { number }\end{array}$ & $\begin{array}{l}\text { Vernacular names } \\
\text { (Specific to } \\
\text { Bitterfontein) }\end{array}$ & Reported use & $\begin{array}{l}\text { Part of } \\
\text { plant used }\end{array}$ & Notes \\
\hline Fabaceae & $\begin{array}{l}\text { Lessertia frutescens (L.) } \\
\text { Goldblatt \& J.C. Manning }\end{array}$ & $\begin{array}{l}\text { P03_01 } \\
\text { (UWC) }\end{array}$ & $\begin{array}{l}\text { Kankerbos/bitterbos/ } \\
\text { kiertjies/blaasiebos }\end{array}$ & $\begin{array}{l}\text { High Blood } \\
\text { Pressure and } \\
\text { Diabetes }\end{array}$ & Leaves & Mostly prepared as a single remedy. \\
\hline Lamiaceae & Leonotis leonurus (L.) R.Br. & $\begin{array}{l}\text { P25_06 } \\
\text { (UWC) }\end{array}$ & Wilde dagga & $\begin{array}{l}\text { High Blood } \\
\text { Pressure and } \\
\text { Diabetes }\end{array}$ & $\begin{array}{l}\text { Leaves, roots } \\
\text { and flowers }\end{array}$ & $\begin{array}{l}\text { The, leaves, roots and flowers are used in a } \\
\text { decoction to treat pain and inflammation } \\
\text { associated with HBP and T2DM. The plant is } \\
\text { also reportedly used as a pain reliever. }\end{array}$ \\
\hline Asteraceae & $\begin{array}{l}\text { Artemisia afra Jacq. ex } \\
\text { Willd. }\end{array}$ & $\begin{array}{l}\text { P06_04 } \\
\text { (UWC) }\end{array}$ & Wilde als & $\begin{array}{l}\text { High Blood } \\
\text { Pressure and } \\
\text { Diabetes }\end{array}$ & Leaves & $\begin{array}{l}\text { A. afra is widely used to treat a variety of } \\
\text { ailments and as a general tonic. A strong } \\
\text { infusion of } A \text {. afra is said to drastically reduce } \\
\text { blood pressure and sugar levels. }\end{array}$ \\
\hline Thymelaeaceae & Gnidia deserticola Gilg & $\begin{array}{l}\text { P11_02 } \\
\text { (UWC) }\end{array}$ & Koorsbos & Diabetes & $\begin{array}{l}\text { Leaves, stems } \\
\text { and roots }\end{array}$ & $\begin{array}{l}\text { G. deserticola is used as a blood purifier, for } \\
\text { respiratory problems, skin rashes, ulcers, snake } \\
\text { bites, colds and flu. A remedy of } L \text {. frutescens, } \\
\text { G. deserticola and B. africana are used for } \\
\text { diabetes and pain relief. }\end{array}$ \\
\hline Lamiaceae & Salvia africana-caerulea $\mathrm{L}$. & $\begin{array}{l}\text { P10_04 } \\
\text { (UWC) }\end{array}$ & Blousalie/bloublomsalie & $\begin{array}{l}\text { High Blood } \\
\text { Pressure }\end{array}$ & Leaves & $\begin{array}{l}\text { Combined with Epsom salts and lemon juice to } \\
\text { treat colic, diarrhoea, flatulence, heartburn and } \\
\text { indigestion. Mixed with L. frutescens to treat } \\
\text { fever, rashes and headaches associated with } \\
\text { HBP. }\end{array}$ \\
\hline Lamiaceae & Ballota africana (L.) Benth & $\begin{array}{l}\text { P18_02 } \\
\text { (UWC) }\end{array}$ & Kattekruid & $\begin{array}{l}\text { High Blood } \\
\text { Pressure }\end{array}$ & Leaves & $\begin{array}{l}\text { As a tea to treat coughs, colds, sore throats, } \\
\text { influenza, asthma, bronchitis, colic and fever. }\end{array}$ \\
\hline Asphodelaceae & Aloe ferox Mill. & $\begin{array}{l}\text { P10_02 } \\
\text { (UWC) }\end{array}$ & Bitter alwyn & Diabetes & Leaves/sap & $\begin{array}{l}\text { The sap of A. ferox is widely used for cuts, sores } \\
\text { and burns, as strong laxative and blood purifier. }\end{array}$ \\
\hline Rutaceae & Diosma oppositifolia L. & $\begin{array}{l}\text { P07_02 } \\
\text { (UWC) }\end{array}$ & Skaapbos & $\begin{array}{l}\text { High Blood } \\
\text { Pressure }\end{array}$ & $\begin{array}{l}\text { Leaves, stems } \\
\text { and flowers }\end{array}$ & $\begin{array}{l}\text { Used with } E \text {. rhinocerotis as a remedy for acute } \\
\text { cases of HBP. As a general tonic it is used for } \\
\text { pain, coughs and colds and for stomach } \\
\text { complaints. }\end{array}$ \\
\hline Asteraceae & $\begin{array}{l}\text { Dicerothamnus } \\
\text { rhinocerotis (L.f.) Koek. }\end{array}$ & $\begin{array}{l}\text { P16_02 } \\
\text { (UWC) }\end{array}$ & Ranosterbos & $\begin{array}{l}\text { High Blood } \\
\text { Pressure and } \\
\text { Diabetes }\end{array}$ & $\begin{array}{l}\text { Leaves and } \\
\text { stem }\end{array}$ & $\begin{array}{l}\text { Used in a remedy together with } D \text {. oppositifolia } \\
\text { to treat stomach complaints including } \\
\text { indigestion, stomach cancer and a lack of } \\
\text { appetite. The dried stems are used to treat } \\
\text { diarrhoea. Also used for fever and inflammation } \\
\text { associated with HBP. }\end{array}$ \\
\hline Aizoaceae & $\begin{array}{l}\text { Sceletium tortuosum (L) } \\
\text { N.E. Br. }\end{array}$ & $\begin{array}{l}\text { P15_02 } \\
\text { (UWC) }\end{array}$ & Kougoed & $\begin{array}{l}\text { High Blood } \\
\text { Pressure }\end{array}$ & $\begin{array}{l}\text { Leaves and } \\
\text { roots }\end{array}$ & $\begin{array}{l}\text { S. tortuosum is used as a single remedy for pain, } \\
\text { stress and anxiety. Although not directly } \\
\text { associated with HBP reduction, it is used to } \\
\text { reduce anxiety and therefore reduce blood } \\
\text { pressure. }\end{array}$ \\
\hline Asteraceae & Tagetes minuta $\mathrm{L}$. & $\begin{array}{l}\text { P25_10 } \\
\text { (UWC) }\end{array}$ & Koebiebos & Diabetes & Leaves & $\begin{array}{l}\text { The sap and stems are poisonous. Dried leaves } \\
\text { are used to make a tea to manage pain, } \\
\text { inflammation and as a blood purifier. }\end{array}$ \\
\hline Crassulaceae & Crassula muscosa $\mathrm{L}$. & $\begin{array}{l}\text { P03_02 } \\
\text { (UWC) }\end{array}$ & Akkedisbos & $\begin{array}{l}\text { High Blood } \\
\text { Pressure and } \\
\text { Diabetes }\end{array}$ & $\begin{array}{l}\text { Leaves, } \\
\text { stems, roots } \\
\text { and flowers }\end{array}$ & $\begin{array}{l}\text { A decoction of the leaves in boiling water is used } \\
\text { for colds, flu, fevers and stomach complaints. } \\
\text { The flowers and roots are dried, grated and } \\
\text { consumed with thick milk for stomach } \\
\text { complaints. }\end{array}$ \\
\hline Crassulaceae & $\begin{array}{l}\text { Tylecodon paniculatus } \\
\text { (L.f.) Toelken }\end{array}$ & $\begin{array}{l}\text { P25_2 } \\
\text { (UWC) }\end{array}$ & Bees se bal & Diabetes & $\begin{array}{l}\text { Leaves and } \\
\text { stem }\end{array}$ & $\begin{array}{l}\text { The heated leaves and stems are placed on } \\
\text { wounds, rashes and sores. The sap from leaves } \\
\text { and stems are used as a purgative and blood } \\
\text { purifier. }\end{array}$ \\
\hline Asteraceae & Chrysocoma ciliata $\mathrm{L}$. & $\begin{array}{l}\text { P02_05 } \\
\text { (UWC) }\end{array}$ & Bitterbos & $\begin{array}{l}\text { High Blood } \\
\text { Pressure and } \\
\text { Diabetes }\end{array}$ & $\begin{array}{l}\text { Leaves and } \\
\text { roots }\end{array}$ & $\begin{array}{l}\text { A decoction of the leaves and roots are used for } \\
\text { gout, rheumatism, fever and constipation. }\end{array}$ \\
\hline Apocynaceae & $\begin{array}{l}\text { Hoodia gordonii (Masson) } \\
\text { Sweet ex Decne }\end{array}$ & $\begin{array}{l}\text { P26_01 } \\
\text { (UWC) }\end{array}$ & Bitterghaap & Diabetes & Inner stem & $\begin{array}{l}\text { Inner stem is consumed as a blood purifier and } \\
\text { to control blood sugar. }\end{array}$ \\
\hline Asteraceae & $\begin{array}{l}\text { Euryops abrotanifolius (L.) } \\
\text { DC. }\end{array}$ & $\begin{array}{l}\text { P08_02 } \\
\text { (UWC) }\end{array}$ & Harpuisbos & $\begin{array}{l}\text { High Blood } \\
\text { Pressure and } \\
\text { Diabetes }\end{array}$ & $\begin{array}{l}\text { Stem and } \\
\text { leaves }\end{array}$ & $\begin{array}{l}\text { Mixed with } E \text {. rhinocerotis and D. oppositifolia } \\
\text { as a general tonic for HBP and T2DM. } E \text {. } \\
\text { abrotanifolius is also known for treating chest } \\
\text { complaints. }\end{array}$ \\
\hline Lamiaceae & Mentha longifolia (L) L. & $\begin{array}{l}\text { P01_01 } \\
\text { (UWC) }\end{array}$ & Ballerja & $\begin{array}{l}\text { High Blood } \\
\text { Pressure and } \\
\text { Diabetes }\end{array}$ & $\begin{array}{l}\text { Stem and } \\
\text { leaves }\end{array}$ & $\begin{array}{l}\text { A decocotion of the leaves are used for } \\
\text { headaches, respiratory ailments, coughs and } \\
\text { colds and for general stomach complaints. } M \text {. } \\
\text { longifolia is added to other plant combinations } \\
\text { to reduce side effects and improve taste. }\end{array}$ \\
\hline Convolvulaceae & $\begin{array}{l}\text { Convolvulus capensis } \\
\text { Burm. f. }\end{array}$ & $\begin{array}{l}\text { P25_05 } \\
\text { (UWC) }\end{array}$ & Bitterpatat & $\begin{array}{l}\text { High Blood } \\
\text { Pressure and } \\
\text { Diabetes }\end{array}$ & Bulb & $\begin{array}{l}\text { The bulb of } C \text {. capensis is dried, grated and } \\
\text { boiled as a general tonic for stomach ailments } \\
\text { and blood purification. }\end{array}$ \\
\hline Apiaceae & $\begin{array}{l}\text { Lichtensteinia lacera } \\
\text { Cham. \& Schltdl. }\end{array}$ & $\begin{array}{l}\text { P18_04 } \\
\text { (UWC) }\end{array}$ & Kaalmoes & $\begin{array}{l}\text { High Blood } \\
\text { Pressure and } \\
\text { Diabetes }\end{array}$ & $\begin{array}{l}\text { Stem and } \\
\text { leaves }\end{array}$ & $\begin{array}{l}\text { L. lacera is drank as a tea for stomach ailments } \\
\text { and a general tonic for cold and flu. }\end{array}$ \\
\hline
\end{tabular}




\begin{tabular}{|c|c|c|c|c|c|c|}
\hline Family & Species & $\begin{array}{l}\text { Voucher } \\
\text { number }\end{array}$ & $\begin{array}{l}\text { Vernacular names } \\
\text { (Specific to } \\
\text { Bitterfontein) }\end{array}$ & Reported use & $\begin{array}{l}\text { Part of } \\
\text { plant used }\end{array}$ & Notes \\
\hline Geraniaceae & $\begin{array}{l}\text { Pelargonium } \\
\text { antidysentericum (Eckl. \& } \\
\text { Zeyh.) Kostel. }\end{array}$ & $\begin{array}{l}\text { P04_05 } \\
\text { (UWC) }\end{array}$ & Rooistorm & Diabetes & Roots & $\begin{array}{l}\text { A tea made of the dried roots is taken for a } \\
\text { variety of stomach ailments. The same tea is } \\
\text { consumed once a day as a general tonic for } \\
\text { T2DM. }\end{array}$ \\
\hline Capparaceae & $\begin{array}{l}\text { Cadaba aphylla (Thunb.) } \\
\text { Wild }\end{array}$ & $\begin{array}{l}\text { P25_12 } \\
\text { (UWC) }\end{array}$ & Swartstorm & $\begin{array}{l}\text { High Blood } \\
\text { Pressure and } \\
\text { Diabetes }\end{array}$ & $\begin{array}{l}\text { Stem and } \\
\text { leaves }\end{array}$ & $\begin{array}{l}\text { The dried leaves and stem are drunk as a tea for } \\
\text { stomach complaints and as a general tonic. }\end{array}$ \\
\hline Anacardiaceae & $\begin{array}{l}\text { Searsia burchellii (Sond. ex } \\
\text { Engl.) Moffett. }\end{array}$ & $\begin{array}{l}\text { P09_02 } \\
\text { (UWC) }\end{array}$ & Taaibos & $\begin{array}{l}\text { High Blood } \\
\text { Pressure and } \\
\text { Diabetes }\end{array}$ & $\begin{array}{l}\text { Leaves, stem } \\
\text { and roots }\end{array}$ & $\begin{array}{l}\text { The leaves and stem of } S \text {. burchellii are used } \\
\text { raw to treat cuts and sores. The fresh leaves are } \\
\text { drunk as a tea for stomach complaints and } \\
\text { fever. }\end{array}$ \\
\hline Amaryllidaceae & Tulbaghia violacea Harv. & $\begin{array}{l}\text { P01_03 } \\
\text { (UWC) }\end{array}$ & Wilde knoffel & $\begin{array}{l}\text { High Blood } \\
\text { Pressure and } \\
\text { Diabetes }\end{array}$ & $\begin{array}{l}\text { Leaves and } \\
\text { roots }\end{array}$ & $\begin{array}{l}\text { The roots of } T \text {. violacea are used in a bath to } \\
\text { ease rheumatism and fever. A tea of roots and } \\
\text { leaves are used to treat coughs and colds and } \\
\text { also to manage HBP. }\end{array}$ \\
\hline
\end{tabular}

In a study conducted on Vervet monkeys, no adverse reactions were reported to high dosages of aqueous extracts of L. frutescens (Seier et al., 2002). In South Africa a Phase I double-blind, placebo-controlled study on healthy individuals found that $400 \mathrm{mg}$ of leaf powder capsule twice a day for three months was tolerated without adverse effects (Johnson et al., 2007). A preclinical study by Minocha et al. (2011) does however indicate that the co-administration of L.frutescens with nevirapine could affect the pharmacokinetics of this drug in rats. Wilson et al. (2015) reported that in a clinical trial on L. frutescens two participants developed tuberculosis while also taking isoniazid preventive therapy (IPT). According to the study the THM may have reduced the efficacy of IPT.

Diosma oppositifolia was also frequently used for the management of HBP and/or T2DM in this study. This species has been described as a broad-spectrum tonic, used in the treatment of intestinal discomfort, kidney problems, occasionally for external sprains and flatulence (Nortje, 2011; Philander, 2011). The leaves are sometimes infused in brandy or vinegar, and synthesizing tinctures used for bruises and sprains ( Philander, 2011). At present, there is no available literature on scientific studies concerning anti-diabetic or antihypertensive properties, nor is there any information regarding the toxicity of this plant.

Gnidia deserticola is a member genus of the family Thymelaeaceae, consisting of approximately 152 species (Bhandurge et al., 2013). There is no information in the literature of Gnidia being used to treat HBP and T2DM, though members of the genus are used for a wide array of conditions, ranging from asthma to nightmares, to yellow fever (e.g. Borris et al., 1998; Van-Wyk et al., 2005). Some Gnidia species have displayed severe irritant properties, leading to death in animals and humans owing to the prevalence of toxic coumarins and diterpene esters. Adverse symptoms resulting from Gnidia intake include inflammation of the larynx, edema 
of the islands, vomiting, discharge of blood upon desiccation, rapid pulse, moist skin, muscular twitching and delirium. These symptoms are followed by convulsion and death in 20-25\% of cases (Bhandurge et al., 2013). The toxicity of the genus raises some concern as it is readily used in plant preparations in Bitterfontein.

Tulbaghia violacea has reportedly been used to treat HBP and T2DM, but also fevers, influenza, intestinal worms, oral infections, asthma and tuberculosis (Raji et al., 2015; Lyantagaye, 2011; Moodley et al., 2015). T. violacea falls within the same family as Allium sativum L., a species utilised as a remedy for T2DM in traditional Indian medicine (Mukherjee et al., 2006). Other members of the family possess similar phytochemical compounds (Cox and Ballick, 1994; Motsei et al., 2003), such as T. violacea, which contains sulphur compounds: often accounting for the distinguishing odours and the medicinal potential of both the Tulbaghia and Allium species (Lyantagaye, 2011). Aqueous extracts of T. violacea show substantial glucose uptake in Chang liver cells. T. violacea contains phytochemical components such as steroidal saponins, quercetin, kaempherol, sugars, and/or sulphur-containing compounds (Duncan et al., 1999) which could have potential glucose-lowering effects. Similarly, sulphur containing compounds in this species have been found to result in hypoglycemic effects in diabetic animals, arising from their antioxidant activity (Mukherjee et al., 2006).

Infusions of $\mathrm{T}$. violacea extracts have been found to decrease systolic blood pressure (SBP) in male spontaneously hypertensive Wistar rats (SHR) (Raji et al.,2015) and in normotensive male Wistar rats (Ramesar et al., 2008), compared to the corresponding values in the control rat groups in experiments. A study by Lyantagaye (2011) examined the effects of $\mathrm{T}$. violacea methanolic extract on blood glucose, serum lipids and anti-oxidative status in streptozotocin induced diabetic rats. Plasma insulin levels were found to be significantly reduced in the diabetic control and treated diabetic groups compared to the non-diabetic control group ( $p$ $<$ o.001). T. violacea treatment produced a notable hypoglycemic effect by dropping fasting glucose levels and cultivating glucose tolerance. The antioxidant activity of T. violacea has been attributed to the presence of organo sulphur compounds, which are believed to possess powerful antioxidant properties capable of stimulating liver antioxidant enzymes (Günthner, 2009). It has been noted that prolonged and excessive use of $\mathrm{T}$. violacea bulbs causes gastrointestinal distress and may be related to acute inflammation and sloughing off of intestinal tissue, as well as the interruption of peristalsis (Lyantagaye, 2011). Artemisia afra is extensively utilised in Southern Africa for the treatment of T2DM, as well as for coughs, colds, headaches, loss of appetite, gastric imbalances, colic, gout, asthma, malaria, kidney and bladder disorders, influenza, convulsion, fever, heart inflammation, rheumatism and as a purgative (Watt and Breyer-Brandwijk, 1962; Thring and Weitz, 2006; Patil et al., 2011; Afolayan, 2013; Mukinda et al., 2010; Mukina and Syce 2007). Sunmonu and Afolayan (2010) evaluated the antioxidant properties of aqueous extract of A. afra leaves on the kidney and liver of rats with 
streptozotocin-induced diabetes. Its effectiveness was found to be comparable to glibenclamide, a standard hypoglycaemic drug. Several of the complications of T2DM have been associated with oxidative stress and antioxidants have been considered as potential treatments (Reaven et al., 1995; Cunningham, 1998). As such, antioxidant action could play a significant role in the treatment of diabetes through THM with this property. This may be an indication that A. afra extract could potentially be a useful therapeutic instrument for treating oxidation-related pathological damage (Wongkham et al., 2001). Issa and Bule (2015) found that blood glucose levels in Alloxan induced diabetic Swiss albino mice significantly decreased (by 24\%) in groups that were given A.afra doses of $500 \mathrm{mg} / \mathrm{Kg}$ and by $56.9 \%$ in groups that received $750 \mathrm{mg} / \mathrm{Kg}$, respectively. The methanolic extract of A. afra also lowered blood glucose by $49.8 \%$ in doses of $1000 \mathrm{mg} / \mathrm{Kg}$. The same study also found that A. afra was non-toxic. Other studies pertaining to the bioactivity of A. afra include its potential use as an antifungal agent (Gundidza, 1993), its antibacterial activity (Rabe and van Staden, 1997), as an antioxidant (Burits et al., 2001), its potential toxicity (Elgorashi et al., 2003), and its anticancer (Fouche et al., 2008), anti-tuberculotic (Mativandlela et al., 2008) and anti-malarial (Van der Kooy et al., 2008) effects. It has also been studied for its protective myocardial uses (Sunmonu, Afolayan, 2010), and its influence on the central nervous system (Nielsen et al., 2004). Guantai and Addae-Mensah (1999) found that aqueous A. afra extract $(10-45 \mathrm{mg} / \mathrm{kg}$ ) had a hypotensive effect when tested in vivo (Patil et al., 2011).

The pharmacology of Chrysocoma ciliata L. has not been significantly studied in South Africa. C. ciliate has however been documented in ethnobotancal studies in the north west region of South Africa (Nortje, 2011; De Beer and van wyk, 2011) for its use for stomach complaints, colds and pain. Afolayan et al. (2009) studied the anti-fungal activity of $\mathrm{C}$. ciliate. The species exhibited a strong anti-fungal propensity in relatively low doses. The plant's possible toxicity has not been investigated.

Leonotis leonurus is a widespread species found all over the Cape floristic region. Studies have documented its use and efficacy for both HBP (Kenechukwu, 2004) and T2DM (Afolayan and Sunmonu, 2010). Studies have reported on the antidiabetic, hypoglycemic, anti-convulsant, anti-nociceptive, anti-inflammatory, and anthelmintic activities and properties of L. leonurus (Kuete, 2013). Mnonopi et al. (2012) tested marrubiin, a constituent of L. leonurus and an organic extract of the plant in vitro and in vivo for their antidiabetic propensity and found that it alleviated diabetic symptoms. Further studies have also reported on the immune modulatory effects of L. leonurus (Hurinanthan, 2009). The main psychoactive component of L. leonurus is leonurine. In a medicinal species review, Mazimba (2015) notes that the species has 37 isolated phytochemicals consisting of flavanoids, labdane type diterpenoids and other phenolics detected in acetone and methanol extracts. The essential oils of L. leonurus were also shown to have anti-oxidant and anti-bacterial 
properties. Studies have been done on the plant's toxicology in rats (Kuete, 2014). It showed possible adverse effects on organs, red blood cells and white blood cells (Maphosa et al., 2008).

Although no studies have been done on the anti-diabetic potential of Tagetes minuta it is reported as a "traditional" medicine. Its leaves and stem are used to make a decoction for pain, inflammation, and as a blood purifier in the case of T2DM. A study conducted by Al-Musayeib et al. (2014) documented T. minuta's anti-oxidative and anti-inflammatory effects. A phytochemical investigation of the methanolic extract of $T$. minuta leaves resulted in the isolation and identification of new compounds: 5-methyl-2,2',5',2",5",2'",5'",2"'"quinquethiophene (1) and quercetagetin-6-O-(6-Ocaffeoyl- $\beta$-D-glucopyranoside)(9) (Karimiana et al., 2014). While T. minuta is widely used and considered to be safe, its oil and extracts can cause photo-toxicity (Scientific Committee on Consumer Safety, 2015).

Hoodia gordonii is native to the Kalahari desert in southern Africa (van Heerden, 2008). The species has received a lot of media and scientific scrutiny as an appetite suppressant and dietary supplement, but not for the management of HBP or T2DM. The active ingredient in $\mathrm{H}$. gordonii is the appetite-suppressing molecule, P57, or oxypregnane steroidal glycoside P57AS3.3 (Madgula et al., 2008). In clinical studies, P57 has been evaluated for its potential as an anti-obesity drug. It is argued that $\mathrm{P}_{57}$ mimics the action of glucose on the brain. Clinical studies have found that $\mathrm{H}$. gordonii is non-toxic (Maharajah, 2001), although side effects of $\mathrm{H}$. gordonii based products have been reported. In a study conducted by Roza et al. (2013), an H. gordonii product was tested for sympathomimetic activity. Through isolated organ experiments on rat uterine rings, the product was found to have smooth muscle relaxant effects with a substantial component mediated through $\beta$ adrenergic receptors. It was also argued that cardiovascular effects of the product may be linked to the $H$. gordonii compounds. Studies have associated the administration of $\mathrm{H}$. gordonii extract with an increase in blood pressure and pulse rate.

Aloe ferox has traditionally been used for cuts, sores and burns. It is also a strong laxative and blood purifier. Much of the clinical data available for A. ferox is based on other studies done on Aloe vera and Aloe arborescens species. Loots et al. (2011) for example conducted a study to investigate the possible anti-diabetic effects of ethanol extracts of A. ferox and A. greatheadii var. davyana leaf gel in a streptozotocin (STZ)-induced T2DM rat model. It was found that supplementation with the species A. greatheadii and A. ferox moderately increased serum insulin with minor corrections in ALP and HDL-C and no change to end-point plasma glucose values which resulted in a clinically relevant improved diabetic state, suggesting that these Aloe species may show promise for managing T2DM. The literature does not refer to it as possible treatment for HBP per se although A. ferox 
leaf gel has promise for the prevention or alleviation of symptoms associated with cardiovascular diseases (Du et al., 2007). A. ferox has a laxative effect but is safe for human use (Celestino et al., 2013; Mahomoodally, 2013).

At present, there is little information available on the anti-diabetic and antihypertensive activity of Convolvulus capensis Burm. f., Pelargonium antidysentericum (Eckl. \& Zeyh.), Carpobrotus edulis (L.) L. Bolus, Salvia africana-caerulea L, Mentha longifolia L., Euryops abrotanifolius (L.) DC., Ballota Africana (L.) Benth, Tylecodon paniculatus (L.f.) Toelken and Crassula muscosa (Linnaeus, 1760) and Searsia burchellii (Sond. ex Engl.) Moffett reportedly used in this study. Many of these species have however been documented in ethnobotanical surveys for their use against HBP and T2DM (Nortje, 2011; Mintsa Mi Nzue, 2009; van wyk and Albrecht, 2008; Arendse, 2013; Philander, 2011). They are also widely used as tonics for stomach complaints, colds, fever, rheumatism and many other illnesses. In literature some have been mentioned anecdotally for their traditional uses. For example, Cadaba aphylla (Thunb.) Wild has been documented for its anti-cancer activity (Fouche et al., 2008) and Dicerothamnus rhinocerotis (L.f.) Koek., for its anti-carcinogenic activity (Dwarka, 2012). Lichtensteinia lacera Cham. \& Schltdl. has been listed as a plant frequently used for T2DM, but there is no scientific endorsement of its safety or efficacy (Patil et al., 2012). Sceletium tortuosum (L.) N.E. Br. has been documented for its use in managing T2DM (Semenya and Potgieter, 2014), and for HIV and TB in the Eastern Cape, South Africa (Lawal et al., 2014) This species has also traditionally been used to treat chest complaints, colds, fevers and coughing (Philander, 2011). The plant has been found to be safe in a clinical trial (Nell et al., 2013).

\subsection{Diagnoses}

In the study sample, sixty five (65) participants had previously been medically diagnosed with HBP, 27 with T2DM and 20 were simultaneously diagnosed as diabetic hypertensive. All of these participants were diagnosed by health care professionals at the Bitterfontein satellite clinic, prior to being interviewed. Blood pressure and blood sugar are regularly tested and monitored by clinic and homebased care staff. Similar studies conducted in the Western Cape Province have also reported high occurrence of HBP (Lloyd-Sherlock et al., 2014b), and in T2DM, prevalence's of between $4.4 \%$ and 9.4\% respectively (Erasmus et al., 2012; Bailey et al., 2016). 


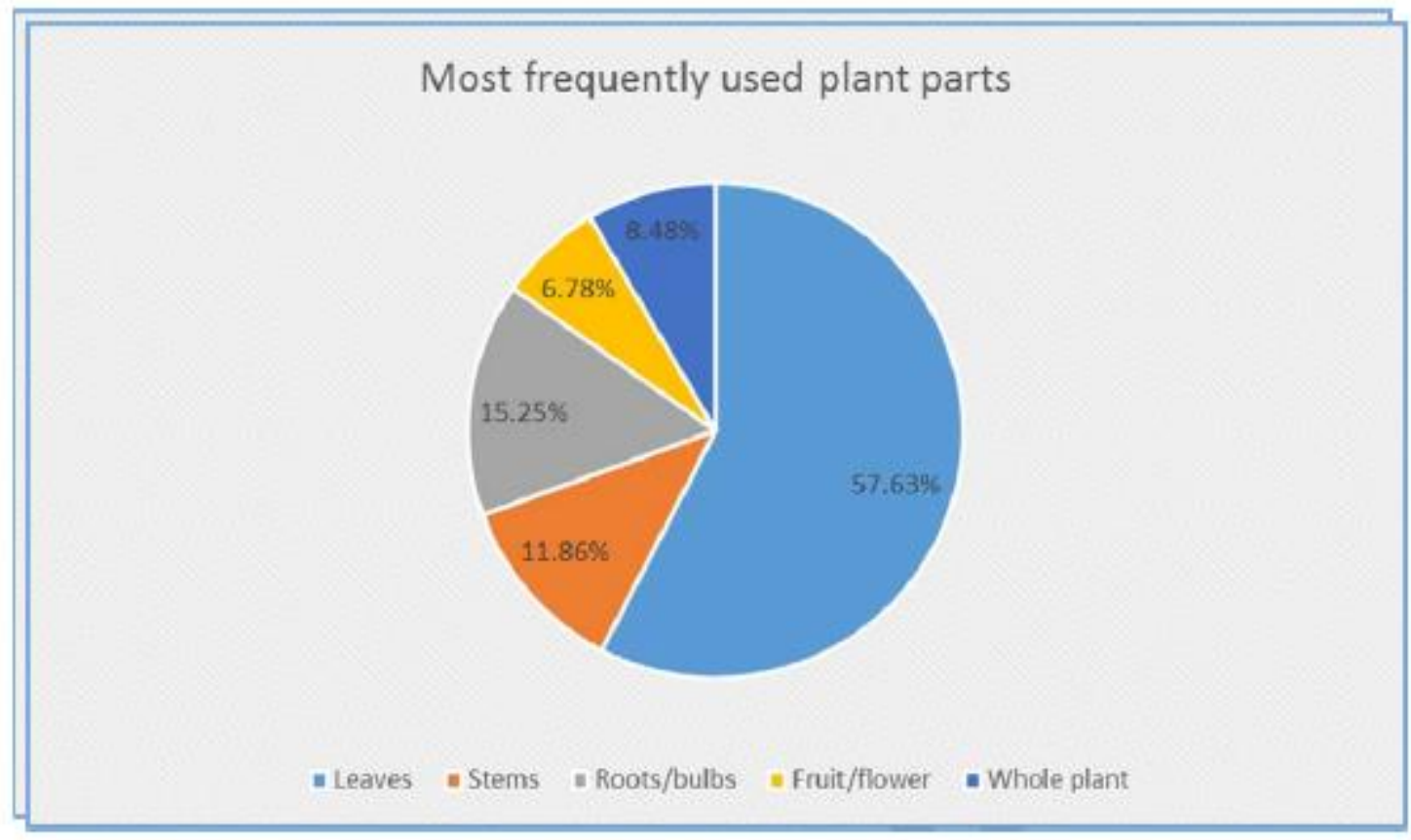

Fig. 2. Plant parts used.

The reported prevalence of $\mathrm{HBP}(8.62 \%)$ and especially T2DM in this study (4.77\%) is comparable. In the Bitterfontein study, $70.4 \%$ of participants with either, or both, conditions are over 40 years of age. Studies have shown that age is a risk factor for HBP and T2DM (Ibid.). Although access to diagnoses, treatment and management of both conditions are generally good in South Africa, a systematic review showed that less than 10\% of T2DM sufferers still do not have access to diagnoses and treatment (Health24, 2014). Between 12.7\% (Erasmus et al., 2012) and 18.1\% (Bailey et al., 2016) were undiagnosed. A large proportion of diagnosed participants in prevalence studies do not manage their conditions with allopathic medicine or refuse to do so (Erasmus et al., 2012; Hughes et al., 2013; Bailey et al., 2016). This may result in the search for alternative therapies and diagnoses, which is often the case in South Africa.

Diagnosed participants generally collected, prepared and consumed plant remedies on their own, or obtained it from knowledgeable elderly family members, neighbours, bossiesdokters or Rastafari bush doctors. They used it for general well-being and to manage symptoms of HBP such as feelings of heat/flushing or sweating, headache, sleeplessness, anxiety and occasional nosebleeds, and for T2DM symptoms such as tiredness, frequent urination, increased hunger and/or thirst, weight loss, dark patches on the skin, blurred vision and lesions that did not heal easily. Plant remedies were also consumed to combat side-effects from their prescribed allopathic medication. These included headaches, dizziness, nausea, stomach pain, tingling in fingers and toes and erratic heart rate. Participants displayed a good understanding of the symptoms of HBP and T2DM based on responses to a range of 
possible symptoms presented to them in the survey questionnaire. Much of the understanding of their conditions is drawn from public information available from the clinic, library and media (radio, television, magazines). Experienced symptoms are explained to them by health care staff.

Since both HBP and T2DM are considered to be linked to lifestyle (poor nutrition, excess salt or sugar, hard labour, stress, etc.) and genetic factors, participants regarded these conditions as natural and did not consult bossiesdokters or Rastafari bush doctors for diagnosis. Instead, bossiesdokters and Rastafari bush doctors were consulted for their specialist knowledge of medicinal plants to use for these (already diagnosed conditions) or for specific and/or persistent symptoms. Although bossiesdokters and Rastafarian bush doctors treated and recommended plant remedies for HBP and T2DM, they generally relied on the information given by a client about a medical diagnosis, or attended to the symptoms a client presented with, before providing a plant remedy. The use of plant remedies, their dosage, mode of administration and duration of use was thus found to be aimed at and dependent on the presence and severity of symptoms.

\subsection{Preparation and administration}

The preparation and administration of each mixture depends on the severity and duration of symptoms. Plants are collected from the commons of Bitterfontein, provided by the elderly or bossiesdokters or bought from Rastafari bush doctors. Sometimes plants are purchased from Rastafari bush doctors in bigger town centres. Here plants are displayed and sold as part of an informal market in THM. In cases where a specific plant is neither available in the area nor present in the veld, 3 participants travel to neighbouring areas to collect them, or order them from bossiesdokters and Rastafari bush doctors who occasionally travel to other areas to collect them. Some of the plants used, such as Tagetes minuta, have been naturalised and often grow in gardens. Elderly participants, who are unable to walk to the veld, often cultivate medicinal plants in their gardens for ease of access. Participants generally preferred to collect plants in the wild, in the spring and summer months when they were more readily available. These seasons are also considered to yield strong plants with high potency.

Plant mixtures varied from one participant to the next as did the use of fresh and dried plant material. When fresh plant material was available, it was generally first dried, as such plants were believed to be stronger. Plants collected from the veld are generally considered more potent and the plant species were mostly used in combinations. Participants did not make a distinction between plants used to treat HBP and T2DM individually. Instead, plant preparations contained up to five plants to address the symptoms of both conditions. Many of the reported preparations included L. frutescens. In some instances, plants were added to combat different symptoms or to make a more potent decoction which would possibly work faster. Plants were also added to a mixture to mediate the side- 
effects of another plant, e.g. G. deserticola, to improve taste and/or as a general tonic. The traditional practice of using multiple plants in a combined decoction has been documented in other studies (Alarcon-Aguilara et al., 1998; Davids et al., 2014; Hughes et al., 2014; Hughes et al., 2015). There is evidence to suggest that the use of multiple plants decreases the probability of resistance to it for a singular condition. In this study, participants explained that multiple plants were used because they complemented one another.

Most of the plant preparations were taken orally, usually prepared as decoctions or infusions. In addition, mixtures were sometimes used for bathing or for inhalation. Topical application of plants were used to treat rashes and sores which took long to heal, especially as a result of T2 DM. The duration of treatment lasted until symptoms or side-effects cleared up, generally within two weeks, at which time the strongest infusions were consumed one to three times a day. Thereafter, preparations were consumed less frequently.

\subsection{Part of plant used}

The leaves (57.63\%) were the most frequently used plant part in preparations for the management of HBP and T2DM. Other plant parts (Fig. 2) were also utilised, but to a lesser extent. The widespread use of leaves in medicinal preparations is well documented in ethnobotanical studies (Hughes et al., 2013; Davids et al., 2014; Hughes. et al., 2015). The traditional belief that leaves are the strongest part of the plant, offering the most potency in relation to other parts, has encouraged their extensive use. It also raises potential concerns about over-use and conservation (Loundou, 2008; Mintsa Mi Nzue, 2009; Street and Prinsloo, 2013).

\subsection{Allopathic medication and THM co-utilisation}

In this study, $48.21 \%$ of diagnosed participants used only allopathic medication for HBP and T2DM. A further $20.11 \%$ of this group had reportedly used THM in the previous four weeks (non-active use). Approximately one third of participants (34.82\%) who had previously been diagnosed with HBP and/ or T2DM used THM along with prescribed allopathic medication, although not simultaneously. While minimal reports (11.6\%) of minor side effects such as nausea and headaches from using both were reported, participants took caution to consume THM at different intervals from their prescribed allopathic medication. They argued that this prevented any potential effects of the plants on the drugs. Similar findings have been reported in other studies. Hughes et al. (2013) found that THM was frequently used together with allopathic medication amongst hypertensives living in South African communities. Liwa et al. (2014) found that 47.5\% of HBP sufferers in sub-Saharan Africa use allopathic medication together with THM. Davids et al. (2014) showed that traditional health practitioners from Strand, Western Cape readily treat HIV and related opportunistic infections with medicinal plant preparations, while patients are on antiretroviral therapy. Hughes et al. 
(2015) found that HIV positive patients used THM in conjunction with allopathic medication, with no reported side-effects.

At present, allopathic medication as a single or in multi-drug therapies cannot return blood glucose levels to normal or maintain blood pressure and there are many reported side-effects of its use (Chethan et al., 2014). Plants are therefore a potentially useful source of complementary supplements for maintaining blood pressure, blood glucose levels and preventing chronic complications in T2DM (Gallagher et al., 2003). In this regard, recent studies have investigated the synergistic use of plant products in combination with allopathic medication. For example, Aiyegoro and Okoh (2009) conducted research on the bio-microbial activity of plant products in combination with allopathic medication against antimicrobial chemotherapy and they argue that plant products can potentially act as synergistic enhancers when used in combination with allopathic medication. Sibanda and Okoh (2008) investigated the interactions between acetone extracts of Garcinia kola seeds and antibiotics. Oliveira et al. (2015) found that there was a possibility of interaction when using medicinal herbs and allopathic medication together.

Despite its occurrence, concurrent use of THM and allopathic medication has not received much scientific scrutiny (Amira and Okubadejo, 2007; Olisa and Oyelola, 2009; Hughes et al., 2015). In part, the concurrent use of allopathic medication and THM is attributed to the limitations of allopathic medication, shortages of health care service providers (Steyn et al., 2008), insufficient access to allopathic medication, patient perceptions about allopathic medication and how it interacts with bodily processes (Cohen, 2009), and the adverse side-effects of some allopathic medications. Plant preparations are generally believed to be effective with fewer side-effects (Erasto, 2005). In this study, 16.97\% of diagnosed participants used only THM, to manage HBP and T2DM. Health care practitioners, service providers and users alike should be made aware of the possible implications for using THM as the sole form of therapy.

\subsection{Conservation}

In South Africa, numerous biodiversity and conservation strategies, organizations such as Cape Nature, the Plant Conservation Alliance (PCS), the Global strategy for plant conservation (GSPC) and the South African National Biodiversity Institute's Red List of plants, are in place to protect, preserve and monitor vulnerable plant groups. A national strategy for plant conservation is also being developed (Ralston et al., 2009; SANBI, 2014; Victor et al., 2015). Mountainous habitats and nature reserves are generally well conserved in South Africa, but lowland regions and especially the Renosterveld area is prone to biodiversity pressures such as fire, agriculture, invasive alien species, pollution, urbanization and climate change (Kemper et al., 1999; Von Staden et al., 2013). In relation to medicinal plants, several studies in South Africa have shown the impact of over-harvesting in the 
trade of such plants (Cocks and Dold, 2004; Cunningham, 2003; Mander et al., 2007; Street et al., 2008; Loundou, 2008; Moeng and Potgieter, 2011). Many medicinal plants are threatened and some are extinct (Street et al., 2008).

The extensive use (35.59\%) of roots/bulbs, stems and the whole plant (Fig. 2) in this study pose a potential future risk for conservation of some plant species used in the management of HBP and T2DM. Most of the plant species reported in Bitterfontein (87.5\%) have been evaluated by the South African National Biodiversity Institute's (SANBI, 2015) threatened species programme (Red data list) and were categorized as 'least concern'. This category includes species which have been evaluated against international conservation standards. The focus of the red list is on monitoring species which are at high risk of extinction and as a result the species categorized as of least concern, may still be of high conservation concern. The species Chrysocoma ciliate and Tagetes minuta (8.33\%) were not assessed according to Red list criteria because they are not indigenous, but can be considered "naturalised exotics." Hoodia gordonii (4.17\%) was also not evaluated due to insufficient data. Although $\mathrm{H}$. gordonii is widespread throughout the Cape Floristic Region, the species has undergone a rapid decline as a result of overharvesting.

The low reported prevalence of some of the plant species in this study may be an indication of its scarcity. Biodiversity and conservation strategies are an important tool for monitoring threatened species and should be advocated in rural areas. The use of plants as medicine is a long-standing practice in areas such as Bitterfontein and is part of the health and well-being of THM users. The sustainable conservation of plants, especially medicinal plant species, is important not only because of their value as a potential source of new medicine, but also to conserve species for future use.

The harvesting of plants is closely monitored by Cape Nature in the Western Cape. In Bitterfontein participants employ a range of practices centered on minimal use and sensitivity to plant harvesting. Similar studies conducted in the Western Cape (Olivier, 2012; Philander, 2011, 2014) and Northern Cape (Cohen, 2009, 2013; Nortje, 2011) have shown that most of the plants harvested, used and sold by bossiesdokters and Rastafari bush doctors are not endangered. Furthermore, these studies have shown that bossiesdokters (Cohen, 2013) and Rastafari bush doctors (Olivier, 2012) have a good sense of awareness of plant conservation. Overall, participants in this study reportedly only collected plant material as they needed it, and in moderate quantities. Most THM users did not harvest plants for sale, nor did they store large quantities of plant material for future use. When collecting plants, participants harvested samples from multiple mature specimens and did not harvest young plants. Although participants collected from Bitterfontein commons, they also varied their collection locations from time to time. They were careful not to disturb the growth of the plant by uprooting it except when the roots 
and bulbs were needed for specific remedies and symptoms. Specific species, which are known to be scarce, were often substituted with other species which are believed to possess similar properties. The predominant use of leaves (57.63\%) and of multiple plant species for the same application also suggests these as possible conservation strategies by locals to prevent over-harvesting of specific species and to safeguard its future use.

\section{Conclusions}

Twenty-four plant species belonging to 15 families were identified and documented for the management of HBP and T2DM. Lessertia frutescens was the most frequently reported plant species among all THM users in this study. This is suggestive of its importance as ethnomedicine for the management of HBP and T2DM in Bitterfontein. Medicinal plant concoctions contained up to five plant species mostly prepared as infusions and decoctions for oral administration.

Although, HBP and T2DM sufferers consulted and received treatment from bossiesdoktors and Rastafari bush doctors, they always relied on biomedical diagnoses before managing the symptoms of either condition with THM. Medicinal plants are widely used by HBP and T2DM sufferers who employ diverse plant species to manage the symptoms of both conditions. Plant collectors employ a range of plant conservation methods to ensure its future use. Although sufferers displayed a good understanding of the symptoms of, and biomedical treatment regime for HBP and T2DM, a large proportion of THM users in this study reportedly used their prescribed allopathic medication together with medicinal plants. They reported minor side-effects. The potential interaction of some of the plant species used with allopathic medication has not received much scientific scrutiny in the past. Health care providers could be sensitized to the pluralistic treatment choices of HBP and T2DM sufferers and to the possibility of herb-drug interaction. Nevertheless, the use of THM continues to be a potential source of new and alternative strategies to manage chronic conditions such as HBP and T2DM.

\section{Author's contributions}

DD, DG and QJ conceptualised the study and designed the methods. DD and DG conducted the ethnobotanical survey and collected the plants. DD and DG transcribed and analysed the data. DD, DG and QJ contributed towards the writing and reviewed the manuscript. All authors read and approved the final manuscript.

\section{Declaration of interests}

The authors declare that they have no competing interests. 


\section{Acknowledgements}

This study was funded by the National Research Foundation (NRF): Knowledge encounters: Cape herbal medicine practices (Grant No: 87804). The authors would like to acknowledge survey participants, bossiesdokters and Rastafari bush doctors from Bitterfontein. The authors also thank the district ward councillor for Bitterfontein, Matzikama Municipality. 


\section{References}

Abe, Y., Umemura, S., Sugimoto, K., Hirawa, N., Kato, Y., Yokoyama, N., Yokoyama, T., Iwai, J., Ish, M., 1995. Effect of green tea rich in $\gamma$ aminobutyric acid on blood pressure of dahl salt sensitive rats. Am. J. Hypertens. 8 (1), 74-79.

Afolayan, A.J., Sunmonu, T.O., 2013. Protective role of Artemisia afra aqueous extract on tissue antioxidant defense systems in streptozotocin-induced diabetic rats. Afr. J. Tradit. Complement. Altern. Med. 10 (1), 15-20.

Afolayan, A.J., Taofik, O., Sunmonu, T.O., 2009. In vivo studies on antidiabetic plants used in South African herbal medicine. J. Clin. Biochem. Nutr. 47, 98-106.

Aiyegoro, O.A., Okoh, A.I., 2009. Use of bioactive plant products in combination with standard antibiotics: implications in antimicrobial chemotherapy. J. Med. Plants Res. 3 (13), 1147-1152.

Alarcon-Aguilara, F.J., Roman-Ramos, R., Perez-Gutierrez, S., AguilarContreras, A., Contreras-Weber, C.C., Flores-Saenz, J.L., 1998. Study of the anti-hyperglycemic effect of plants used as antidiabetics. J. Ethnopharmacol. 61, 101-109.

Al-Musayeib, N., Mohamed, G., Ibrahim, S., Ross, S., 2014. New thiophene and flavonoid from tagetes minuta leaves growing in Saudi Arabia. Molecules $19,2819-2828$.

Amira, O.C., Okubadejo, N.U., 2007. Frequency of complementary and alternative medicine utilization in hypertensive patients attending an urban tertiary care centre in Nigeria. BMC Complement. Altern. Med. 7, 30 .

Arendse, M.L., 2013. Medicinal Plant Use in the Dwarsrivier Valley, Stellenbosch (Unpublished MSc thesis). University of the Western Cape, Bellville.

Atal, C.K., 1983. Potential Newer Medicinal Plants: Report of the Seminar on Medicinal Plants, Phytochemical and Bulk Drugs. Chemexcil, Cooperage Road, Bombay, India. pp. 34-36.

Bailey, S.L., Ayles, H., Beyers, N., Faussett, P.G., Muyoyeta, M., du Toit, E., Yudkin, J.S., Floyd, S., 2016. Diabetes mellitus in Zambia and the Western Cape province of South Africa: prevalence, risk factors, diagnosis and management. J. Diabetes Res. Clin. Pract. 118 (1), 1-11.

Balogun, W.O., Salako, B.L., 2011. Co-occurrence of diabetes and hypertension: pattern and factors associated with order of diagnosis among Nigerians. Ann. Ib. Postgrad. Med. 9 (2), 89-93.

Bates, S.H., Jones, R.B., Bailey, C.J., 2000. Insulin-like effect of pinitol. Br. J. Pharmacol. 130 (8), 1944-1948. 
Bhandurge, P., Rajarajeshwari, N., Ganapaty, S., Pattanshetti, S., 2013. The Gnidia genus: a review. Asian J. Biomed. Pharm. Sci. 3 (19), 1-31.

Borris, R.P., Blasko, G., Cordell, G.A., 1998. Ethnopharmacologic and Phytochemical studies of Thymelaeaceae. J. Ethnopharmacol. 24, 41-91.

Bothma, B., 2014. Diabetes Still a Major Ccause of Death in SA. eNCA. 14th November. Available from: 〈https://www.enca.com/southafrica/diabetes-still-major-cause-death-sa). (Accessed 16/5/2015).

Burits, M., Asres, K., Bucar, F., 2001. The antioxidant activity of the essential oils of Artemisia afra, Artemisia abyssinica and Juniperus procera. Phytotherapy Research 15 (2), 103-108.

Carretero, O., Oparil, S., 2000. Clinical Cardiology: New Frontiers. Available from: 〈http://circ.ahajournals.org/content/101/3/329.long〉. (accessed 11/04/15).

Celestino, V.R.L., Maranhão, H.M.L., Vasconcelos, C.F.B., Lima, C.R., Medeiros, G.C.R., Araújo, A.V., Wanderley, A.G., 2013. Acute toxicity and laxative activity of Aloe ferox resin. Rev. Bras. De. Farmacogn. 23 (2), 279-283.

Chadwick, W.A., Roux, S., van de Venter, M., Louw, J., Oelofsen, W., 2007. Antidiabetic effects of Sutherlandia frutescens in Wistar rats fed a diabetogenic diet. J. Ethnopharmacol. 109 (1), 121-127.

Chethan, J., Kumar, P.M., Prakash, H.S., 2014. Antidiabetic and Antihypertensive Potential of Selected Asteraceae Plant Species. American Journal of Advanced Drug Delivery. Available from: 〈http://eprints.uni-mysore.ac.in/17364/1/PA-500258-\%5B4\%5D.pdf〉. (accessed 11/o9/15).

Cheung, B.M.Y., Chao, Li, C., 2012. Diabetes and Hypertension: is There a Common metabolic pathway. Curr. Atheroscler. Rep. 14 (2), 160-166.

Cocks, M.L., Dold, A.P., Grundy, I.M., 2004. The medicinal plant trade in the Eastern Cape Province of South Africa. In: Lawes, M., Eeley, H., Shackleton, C., Geach, B. (Eds.), The Use and Socio-Economic Value of Indigenous Forest and Woodland Resources in South Africa. University of KwaZulu-Natal Press, Scottsville.

Cohen, J., 2009. Medicine from the Father: bossiesmedisyne, people, and landscape in Kannaland. Anthropol. South. Afr. 32 (1 \& 2), 18-26.

Cohen, J., 2013. Cultivating krag, refreshing gees: Ecologies of wellbeing in Namaqualand. In: L. Green, L. (ed.), Contested ecologies. Dialogues in the South on nature and knowledge. Cape Town, pp 90-109.

Cox, P.A., Ballick, M.J., 1994. The ethnobotanical approach to drug discovery. Sci. Am. 6, 60-65.

Cunningham, J.J., 1998. Micronutrients as nutriceutical intervention in diabetes mellitus. J Am Coll Nutr 17, 7-10.

Cunningham, A.B., 2003. An Africa-wide overview of medicinal plant harvesting, conservation and health care. In: Bodeker, G.K., Bhat, J., Burley, P. (Eds.), Medicinal Plants for Forest Conservation and Health 
Care (Reprint). Food and Agricultural Organisation of the United Nations, Vantomme. Rome, 130-135.

Dalvi, S., 2003. Sutherlandia as support for immunedisfunction. Positive Health Online (85). 〈http://www.positivehealth.com/article/herbalmedicine/sutherlandia-as- support-for-immune-dysfunction $\rangle$

Davids, D., Blouws, T., Aboyade, O., Gibson, D., De Jong, J.T., Van't Klooster, C., Hughes, G., 2014. Traditional health practitioners' perceptions, herbal treatment and management of HIV and related opportunistic infections. J. Ethnobiol. Ethnomed. 10 (77), 2-14.

Davids, D., 2012. Materia Medica and Care: a Study of the uses of Medicinal Herbs and Remedies as a Form of Treatment and Negotiating Social Relationships in Cape Town and Surroundings (Unpublished MA Thesis). University of the Western Cape.

Day, C., 1998. Traditional plants treatments for diabetes mellitus: pharmaceutical foods. Brit. J. Nutr. 80 (1), 5-6.

Deutschländer, M.S., Lall, N., van der Venter, M., 2009. Plant species used in the treatment of diabetes by South African traditional healers. Inventory Pharm. Biol. 47 (1), 348-365.

De Beer, J., van wyk, B-E., 2011. An ethnobotanical survey of the AgterHantam,

Northern Cape Province, South Africa South African. Journal of Botany 77, 741754 .

Dold, A.P., Cocks, M.L., 2002. The trade in medicinal plants in the Eastern Cape Province, South Africa. South Afr. J. Sci. 98 (11/12), 589-597.

Du, T.L., Van Der Westhuizen, F.H., Botes, L., 2007. Aloe ferox leaf gel phytochemical content, antioxidant capacity, and possible health benefits. J. Agric. Food Chem. 55 (17), 6891-6896.

Duncan, A.C., Jager, A.K., van Staden, J., 1999. Screening of Zulu medicinal plants for angiotensin converting enzyme (ACE) inhibitors. J. Ethnopharmacol. 68, 63-70.

Dwarka, D., 2012. Anti-carcinogenic Activity of Centella Asiatica and Elytropappus Rhinocerotis on a Human Colon Cancer Cell Line (Unpublished M.Tch thesis). Durban University of Technology.

Ellen, R., Harris, H., 2000. Introduction. In: Ellen, R., Parkes, P., Bicker, A. (Eds.), Indigenous Environmental Knowledge and its Transformations. Critical Anthropological Perspectives. Harwoord Academic Publishers. Pp, Amsterdam, 1-34.

Elgorashi, E.E., Taylor, J.L., Maes, A., van Staden, J., De Kimpe, N., Verschaeve, L., 2003. Screening of medicinal plants used in South African traditional medicine for genotoxic effects. Toxicol Lett 143 (2), 195-207.

Erasmus, R.V., Soita, D.J., Hassan, M.S., Blanco-Blanco, E., Vergotine, Z., Kengne, A.P., Matsha, T.E., 2012. High prevalence of diabetes mellitus and metabolic syndrome in a South African coloured population: baseline data of a study in Bellville, Cape Town. South Afr. Med. J. 102 (11), 841-844. 
Erasto, P., 2003. Phytochemical Analyses and Antimicrobial Studies on Bolusanthus Speciosus and Cassia Abbreviata (MPhil thesis). University of Botswana, Gaberone.

Erasto, P., Adebola, P.O., Grierson, D.S., Afolayan, A.J., 2005. An ethnobotanical study of plants used for the treatment of diabetes in the Eastern Cape Province, South Africa. Afr. J. Biotechnol. 4 (12), 1458-1460.

Fouche, G., Cragg, G.M., Pillay, P., Kolesnikova, N.I., Maharaj, V.J., Senabe, J., 2008. In vitro anti-cancer screening of South African plants. J. Ethnopharmacol. 119, 455-461.

Gallagher, A.M., Flatt, P.R., Duffy, G., Abdel-Wahab, Y.H.A., 2003. The effects of traditional antidiabetic plants on in vitroglucose diffusion. Nutr. Res. 23 (3), 413-424.

Gibson, D., 2011. Ambiguities in the making of an African Medicine: clinical trials of Sutherlandia frutescens (L.) R.Br 1(Lessertia frutescens). Afr. Sociol. Rev./Rev. Afr. De. Sociol. 15 (1), 123-136.

Guantai, A.N., Addae-Mensah, I., 1999. Cardiovascular effect of Artemisa Afra and its constituents. Pharm. Biol. 37 (1), 351-356.

Gundidza, M., 1993. Antifungal activity of essential oil from Artemisia afra Jacq. Cent Afr J Med 39 (7), 140-142.

Günthner, T., Jankowski, V., Kretschmer, A., Nierhaus, M., van der Giet, M., Zidek, W., Jankowski, J., 2009. Endothelium and vascular smooth muscle cells in the context of Uremia. Semin Dial. 22 (4), 428-432.

Health24, 2014. Prevalence of diabetes in South Africa. Available from: 〈http://www.health24.com/Medical/Diabetes/Aboutdiabetes/Diabetes-tsunami-hits-South-Africa-20130210 .

19/05/15).

Heckathorn, D.D., 2011. Comment: snowball versus respondent-driven sampling. Sociol. Method. 41, 353-366.

Hughes, G., Aboyade, O., Clark, B., Puoane, T., 2013. The prevalence of traditional herbal medicine use among hypertensives living in South African communities. BMC Complement. Altern. Med. 13, 38.

Hughes, G., Blouws, T., Aboyade, O., Davids, D., Mbamalu, O., Van't Klooster, C., De Jong, J., Gibson, D., 2015. An ethnobotanical survey of medicinal plants used by traditional health practitioners to manage HIV and its related opportunistic infections in Mpoza, Eastern Cape Province, South Africa. J. Ethnopharmacol. 171, 109-115.

Hurinanthan, V., 2009. Immune Modulatory Effect of Dichrostachys Cinerea, Carpobrotus Dimidiatus, Capparis Tomentosa and Leonotis Leonurus (Unpublished M.Tch thesis). Durban University of Technology..

Idemyor, V., 2010. Diabetes in Sub-Saharan Africa: health care perspectives, challenges, and the economic burden of disease. J. Natl. Med. Assoc. 102 (7), 650-653. 
Johnson, Q., Syce, J., Nell, H., Rudeen, K., Folk, W.R., 2007. A randomized, double- blind, placebo-controlled trial of Lessertia frutescens in healthy adults. PLOS Clin. Trial 2 (4), e16.

Kadima, F.N., Tumbo, J.M., 2013. Screening of long-term complications and glycaemic control of patients with diabetes attending Rustenburg Provincial Hospital in North West Province, South Africa. Afr. J. Prm Health Care Fam. Med. 5 (1), 375-380.

Karimiana, P., Kavoosia, G., Amirghofranb, Z., 2014. Anti-oxidative and Antiinflammatory effects of Tagetes minuta essential oil in activated macrophages. Asian Pac. J. Trop. Biomed. 4 (3), 219-227.

Kemper, J., Cowling, R.M., Richardson, D.M., 1999. Fragmentation of South African renosterveld shrublands: effects on plant community structure and conservation implications. Biol. Conserv. 90, 109-111.

Kenechukwu, O., 2004. Cardiovascular Effects of Leonotis Leonurus Extracts in Normotensive Rats and in Isolated Perfused Rat Heart (Unpublished M.Pharm. Thesis). University of the Western Cape.

Kuete, V., 2013. Medicinal Plants Research in Africa. Pharmacology And Chemistry. Elsevier, Amsterdam.

Lawal, I.O., Grierson, D.S., Afolayan, A.J., 2014. Phytotherapeutic information on plants used for the treatment of tuberculosis in Eastern Cape Province, South Africa. Evid.- Based Complement. Altern. Med..

Levine, S., 2012. Testing knowledge: legitimacy,legitimacy, healing and medicine in South Africa. In: Levine, S. (Ed.), Medicine and the Politics of Knowledge. HSRC Press, Cape Town, 55-78.

Levitt, N.S., Steyn, K., lambert, E.V., Reagon, G., Lombard, C.J., Fourie, J.M., Rossouw,

K., Hoffman, M., 1999. Modifiable risk factors for Type 2 diabetes mellitus in a peri- urban community in South Africa. Diabet. Med. 16 (11), 946-950.

Liwa, A.C., Smart, A., Frumkin, H.B., Epstein, D., Fitzgerald, W., Peck, R.N., 2014. Traditional Herbal Medicine Use Among Hypertensive Patients in Sub-Saharan Africa: a Systematic Review. Curr. Hypertens. Rep. 16 (6), 437.

Lloyd-Sherlock, P., Beard, J., Minicuci, N., Ebrahim, S., Chatterji, S., 2014a. Hypertension among older adults in low and middle-income countries: prevalence, awareness and control. Int. J. Epidemiol. 1, 1-13.

Lloyd-Sherlock, P., Ebrahim, S., Grosskurth, H., 2014b. Editorial. Is hypertension the new HIV epidemic? Int. J. Epidemiol. 43 (1), 8-10.

Loots, D.T., Pieters, M., Islam, S., Botes, L., 2011. Antidiabetic effects of Aloe ferox and Aloe greatheadii var. davyana leaf gel extracts in a low-dose streptozotocin diabetes rat model. South Afr. J. Sci. 107 (7-8), 46-51.

Loundou, P.M., 2008. Medicinal Plant Trade and Opportunities for Sustainable Management in the Cape Peninsula, South Africa (Unpublished MSc thesis). University of Stellenbosch, Stellenbosch. 
Low, C., 2007. Different Histories of Buchu: Euro-American Appropriation of San and Khoekhoe Knowledge of Buchu Plants. Environ. Hist. 13 (1), $333-361$.

Lyantagaye, S.L., 2011. Ethnopharmacological and phytochemical review of Allium species (sweet garlic) and Tulbaghia species (wild garlic) from Southern Africa. Tanzan. J. Sci. 37, 1.

Mander, M., Ntuli, L., Nicci, D., Mavundlai, K., 2007. Economics of the Traditional Medicine Trade in South Africa. Available from: $\langle$ www.hst.org.za/files/chap13_o7〉. (accessed 13.05.16).

Madgula, V.L.M., Pawar, R.S., Shukla, Y.Z., Avula, B., Walker, L.A., Khan, I.A., Khan, S.I., 2008. Characterization of ADME Properties of P57AS3 and its Aglycone from Hoodia gordonii. Planta Med 74, 59.

Mahomoodally, M.F., 2013. Traditional Medicines in Africa: An Appraisal of Ten Potent African Medicinal Plants. Evid Based Complement. Alternat Med, 617459.

Maphosa, V., Masika, P., Adedapo, A., 2008. Safety evaluation of the aqueous extract of Leonotis leonurus shoots in rats. Hum. Exp. Toxicol. 27 (11), 837-843.

Mativandlela, S.P., Meyer, J.J., Hussein, A.A, Houghton, P.J., Hamilton, C.J., Lall, N., 2008. Activity againstMycobacterium smegmatis and M. tuberculosis by extract of South African medicinal plants. Phytother Res 22, 841-845.

Matzikama Municipality, 2013. Matzikama Spatial development Framework (12.2188) CNdV Africa Planning and Design CC draft status quo report. Bitterfontein. Available from: www.cndv.co.za/.../Matzikama\%20SDF/14\%20-\%2oBitterfontein\%2osec. (accessed 12/2/2015).

Mazimba, O., 2015. Leonotis leonurus: a herbal medicine review. J. Pharmacogn. Phytochem. 3 (6), 74-82.

Minocha, M., Mandava, N.K., Kwatra, D., 2011. Effect of short term and chronic administration of Sutherlandia frutescens on pharmacokinetics of nevirapine in rats. Int. J. Pharm. 413 (1-2), 44-50.

Mnonopi, N., Levendal, R.A., Mzilikazi, N., Frost, C.L., 2012. Marrubiin, a constituent of Leonotis leonurus, alleviates diabetic symptoms. Phytomedicine 19 (6), 488-493.

Moeng, E.T., Potgieter, M.J., 2011. The trade of medicinal plants by muthi shops and street vendors in the Limpopo Province, South Africa. J. Med. Plants Res. 5 (4), 558-564.

Moodley, K., Joseph, K., Naidoo, Y., Islam, S., Mackraj, I., 2015. Antioxidant, antidiabetic and hypolipidemic effects of Tulbaghia violacea Harv. (wild garlic) rhizome methanolic extract in a diabetic rat model. BMC Complement. Altern. Med. 15, 408. 
Moshe, D., 1998. Abiosynthetic study of the genus SutherlandiaBr.R. (Fabacea, Galegeae). M.Sc. Dissertation. Botany Department, Faculty of Natural Sciences. Rand Afrikaans University.

Motsei, M.L., Lindsey, K.L., van Staden, J., Jäger, A.K., 2003. Screening of traditionally used South African plants for antifungal activity against Candida albicans. J. Ethnopharmacol. 86 (1), 235-241.

Mukherjee, P.K., Maiti, K., Mukherjee, K., Houghton, P.J., 2006. Leads from Indian medicinal plants with hypoglycemic potentials. J. Ethnopharmacol. 106, 1-28.

Mukinda, J.T., Syce, J.A., 2007. Acute and chronic toxicity of the aqueous extract of Artemisia afra in rodents. Journal of Ethnopharmacology 112, 138-144.

Mukinda, J.T., Syce, J.A., Fisher, D., 2010. Effect of the Plant Matrix on the Uptake of Luteolin Derivatives-containing Artemisia afra Aqueous-extract in Caco-2 cells. Journal of Ethnopharmacology 130, 439-449.

Nortje, J., 2011. Medicinal Ethnobotany of the Kamiesberg, Namaqualand, Northern Cape Province (MSc thesis). University of Johannesburg.

Nell, H., Siebert, M., Chellan, P., Gericke, N., 2013. A randomized, double-blind, parallel- group, placebo-controlled trial of extract Sceletium tortuosum (Zembrin) in healthy adults. J. Altern. Complement. Med. 19 (11), 898904 .

Nxumalo, N., Alaba, O., Harris, B., Chersich, M., Goudge, J., 2011. Utilization of traditional healers in South Africa and costs to patients: findings from a national household survey. J. Public Health Policy 32 (1), 124-136.

Olisa, N.S., Oyelola, F.T., 2009. Evaluation of use of herbal medicines among ambulatory hypertensive patients attending a secondary health care facility in Nigeria. Int J. Pharm. Pr. 17, 101-105.

Olivier, L., 2012. Rastafari Bush Doctors and the Challenges of Transforming Nature Conservation in the Boland area (MA thesis). Stellenbosch University.

Oliveira, S.G.D., Piva, E., Lund, R.G., 2015. The possibility of interactions between medicinal herbs and allopathic medicines used by patients attended at basic care units of the brazilian unified health system. Nat. Prod. Chem. Res..

Patil, G.V., Dass, S.K., Chandra, R., 2011. Artemisia afra and modern diseases. J. Pharm. Pharm. 2 (3), 1-22.

Philander, L.A., 2011. An ethnobotany of Western Cape Rasta bush medicine. J. Ethnopharmacol. 138 (2), 578-594.

Philander, L., Makunga, N., Ester, K., 2014. The informal trade of medicinal plants by Rastafari bush doctors in the Western Cape South Africa. Econ. Bot. 68 (3), 303-315.

Rabe, T., van Staden, J., 1997. Antibacterial activity of South African plants used for medicinal purposes. J Ethnopharmacol 56 (1), 81-87. 
Ralston, S., de Villiers, C., Manuel, J., Genevieve, P., 2009. Where are we going? Fine scale systematic conservation plans and their contribution to environmental assessment.

Availablefrom:〈http://biodiversityadvisor.sanbi.org/wpcontent/ uploads/2012/08/Ralston_Samantha_et_al_2009.pdf). (accessed 15.08.15).

Raji, I., Obikeze, K., Mugabo, P. 2015. Potential Beneficial Effects of Tulbaghia violacea William Henry Harvey (Alliaceae) on Cardiovascular System - A Review, 14(June), pp. 1111-1117.

Ramesar, S., Baijnath, H., Govender, T., Mackraj, I., 2008. AngiotensinIconverting enzyme inhibitor activity of nutritive plants in KwaZulu-Natal. J. Med. Food 11, 331-336.

Reaven, P.D., Herold, D.A., Barnett, J., Edelman, S., 1995. Effects of vitamin E on susceptibility of low-density lipoprotein and low-density lipoprotein subfractions to oxidation and on protein glycation in NIDDM. Diabetes Care 8, 807-816.

Rood, B., 1994. Uit die veldapteek. Tafelberg Publishers, Cape Town.

Roza, O., Lovász, N., Zupkó, I., Hohmann, J., Csupor, D., 2013. Sympathomimetic activity of a hoodia gordonii product: aa possible mechanism of cardiovascular side effects. BioMed. Res. Int.. http://dx.doi.org/10.1155/2013/171059, (Accessed: 16/ 02/15).

SANBI, 2014. South African National Biodiversity Institute (SANBI) Final Corporate Strategic Plan (CSP) 2014 - 2019. Available from: www.sanbi-final-corporate- strategic-plan-2014-2019-approved-boarddea-14-02-2014_o. (Accessed 11.04.15).

Scientific Committee on Consumer Safety, 2015. Scientific Committee on Consumer Safety opinion on the fragrance ingredients Tagetes minuta and T. patula extracts and essential oils (photo toxicity only). Available from:

〈http://ec.europa.eu/health/ scientificcommittees/consumersafety/docs/sccso172.pdf). (accessed o8.08.16).

Seier, J.V., Mdhluli, M., Dhansay, M.A., Loza, J., Laubscher, R., 2002. A Toxicity Study of

Sutherlandia Leaf Powder (Sutherlandia frutescens sub-species micro- phylla) consumption. Medical Research Council, Tygerberg (South Africa).

Semenya, S.S., Potgieter, M.J., 2014. Bapedi traditional healers in the Limpopo Province, South Africa: their socio-cultural profile and traditional healing practiceJ. Ethnobiol. Ethnomed. 10, 4.

Sia, C., 2004. Spotlight on ethnomedicine: usability of Sutherlandia frutescens in the treatment of diabetes. Rev Diabet Stud 1, 145-149.

Sibanda, T., Okoh, A.I., 2008. In vitro evaluation of the interactions between acetone extracts of Garcinia kola seeds and some antibiotics. Afr. J. Biotechnol. 7 (11), 1672-1678. 
South African National Biodiversity Institute, Red List of South African Plants. Avialable from: 〈http://redlist.sanbi.org/〉. (accessed 11.04.15.).

Statistics South Africa, 2011. Bitterfontein Main Place 160004 from Census 2011. Available from: $\langle$ http://census2011.adrianfrith.com/place/160004〉. (accessed 26/ 1115).

Steyn, K., Levitt, N.S., Patel, M., Fourie, J., Gwebushe, N., Lombard, C., Everett, K., 2008.

Hypertension and diabetes: poor care for patients at community health centres. South Afr. Med. J. 98 (8).

Street, R.A., Stirk, W.A., Van Staden, J., 2008. South African traditional medicinal plant trade-Challenges in regulating quality, safety and efficacy. J. Ethnopharmacol. 119 (3), 705-710.

Street, R.A., Prinsloo, G., 2013. Commercially important medicinal plants of South Africa: a review. J. Chem., 16.

Sunmonu, T.O., Afolayan, A.J., 2010. Protective effect of Artemisia afra Jacq. on isoproterenol-induced myocardial injury in Wistar rats. Food Chem. Toxicol. 48 (7), 1969-1972.

Tai, J., Cheung, S., Chan, E., Hasman, D., 2004. In vitro culture studies of Sutherlandia frutescens on human tumor cell lines. J. Ethnopharmacol. 93 (1), 9-19.

Thring, T.S., Weitz, F.M., 2006. Medicinal plant use in the Bredasdorp/Elim region of the Southern Overberg in the Western Cape Province of South Africa. J Ethnopharmacol 103 (2), 261-275.

van der Kooy, F., Verpoorte, R., Meyer, J.J.M., 2008. Metabolomic quality control of claimed anti-malarial Artemisia afra herbal remedy and A. afra and A. annua plant extracts, South African. Journal of Botany 74 (2), 186-189.

Van Heerden, F.R., 2008. Hoodia gordonii: a natural appetite suppressant. J. Ethnopharmacol. 119 (3), 434-437.

van wyk, B.E., Van Oudtshoorn, B., Gericke, N., 1997. Medicinal Plants of South Africa [2nd improved impression, 2000]. Briza Publications, Pretoria, (ISBN: 1875093 095).

van wyk, B.E., 2008. A review of Khoi-San and Cape Dutch medical ethnobotany. Journal of Ethnopharmacology 119, 331-341.

van wyk, B.E., Albrecht, C., 2008. A review of the taxonomy, ethnobotany, chemistry and pharmacology of Sutherlandia frutescens (Fabaceae). J. Ethnopharmacol. 119 (3), 620-629.

van wyk, B.E., Gericke, N., 2000. Peoples Plants: A Guide To Useful Plants of Southern Africa. Briza Publications,, Pretoria, (ISBN 978187509319 9).

Van-Wyk, B.E., Van Heerden, F., Van Oudtshoorn, B., 2005. Poisonoust Plants of South Africa. Briza Publications, Pretoria.

Victor, J.E., Smith, G.F., van wyk, A.E., 2015. Strategy for plant taxonomic research in South Africa 2015-2020. SANBI Biodiversity Series 26. 
Available from: 〈www. biodiversity-series-26-strategy-plant-taxonomicresearch-sa.PDF $\rangle$. (accessed 23.02.15).

Von Staden, L., Raimondo, D., Dayaram, A., 2013. Taxonomic research priorities for the conservation of the South African flora. S Afr. J. Sci. 109 (3/4), 1182-1192.

Wilson, D., Goggin, K., Williams, K., Gerkovich, M., Gqaleni, N., Syce, J., 2015.

Consumption of Sutherlandia frutescens by HIV-Seropositive South African Adults: an Adaptive Double-Blind Randomized Placebo Controlled Trial. PLoS One. 10 (7), e0128522.

Wongkham, S., Laupattarakasaem, P., Pienthaweechai, K., Areejitranusorn, P., Wongkham, C., et al., 2001. Antimicrobial activity of Streblus asper leaf extract. Phytotherapy Research 15 (2), 119-121.

World Health Organization, Factsheet 134: traditional Medicine. WHO, Geneva. World Health Organisation New data highlight increases in hypertension, diabetes incidence. Availablefrom:〈http://www.who.int/mediacentre/news/releases/2012/ world_health_statistics_20120516/en/. . (accessed 30/05/

World Health Organisation, 2016. Global report on diabetes. Geneva.

Wreford, J., Esser, M., Hippler, S., 2006. Facilitating Relationships between African Traditional Healing and Western Medicine in South Africa in the Time of AIDS: A Case Study from the Western Cape. CSSR Working Paper 170. Centre for Social Science Research, University of Cape Town: Cape Town. 